Eurostudia

\title{
Of Modernity's Boundaries, Border-Runners and Toll-keepers
}

\section{Mathieu Denis et Ulrich Ufer}

Volume 7, numéro 1-2, 2011

Deutschland und Europa : Grenzen und Grenzgänge(r)

L'Allemagne et l'Europe : frontières et passeurs

URI : https://id.erudit.org/iderudit/1015022ar

DOI : https://doi.org/10.7202/1015022ar

Aller au sommaire du numéro

Éditeur(s)

Le Centre canadien d'études allemandes et européennes

ISSN

1718-8946 (numérique)

Découvrir la revue

Citer cet article

Denis, M. \& Ufer, U. (2011). Of Modernity's Boundaries, Border-Runners and Toll-keepers. Eurostudia, 7(1-2), 199-211. https://doi.org/10.7202/1015022ar

Tous droits réservés @ $@$ Le Centre canadien d'études allemandes et européennes, 2012
Ce document est protégé par la loi sur le droit d'auteur. L'utilisation des services d'Érudit (y compris la reproduction) est assujettie à sa politique d'utilisation que vous pouvez consulter en ligne.

https://apropos.erudit.org/fr/usagers/politique-dutilisation/ 
Mathieu Denis

Centre canadien d'études allemandes et européennes, Université de Montréal

Ulrich Ufer

Centre canadien d'études allemandes et européennes, Université de Montréal

B oundaries have always been a part of how people have understood and made sense of their environment. The most fundamental kind of boundary comes in the form of natural geography, which imposed physical boundaries which were either impossible, or difficult, to cross before the advent of modern transportation. By contrast, the imposition of social order represents another kind of boundary. In the attempt to establish order, social organizations have always demarcated their spheres of power, influence and activity, thus implementing and setting up cultural boundaries. And on a psychological and spiritual level, boundaries between imagination and reality, between life and death and between the seen and unseen, have never ceased to intrigue and obsess humankind. Liminality, and hence the recognition of boundaries is what anthropologists call a common human experience; ${ }^{1}$ its meaning varies according to cultural contexts. In this sense, boundaries can be a means towards the end of political sovereignty and a way of stabilizing individual identity. Boundaries can be understood as protective shields against unwelcome intrusions and intruders and as simple brute facts about the world that help to bind a specific community. From another perspective, boundaries can also be criticized and deplored as limits to human activities, or they can be perceived as obstacles which stimulate the capacity and the motivation to surmount them.

\section{CONSTRUCTING AND DECONSTRUCTING BOUNDARIES IN MODERNITY}

Western modernity has put great emphasis on boundary crossing, which it regarded as a promise of advancement. One of the clearest expressions of this approach was formulated long ago by Frederick J. Turner in his 1893 essay on the significance of the frontier in American history. As a meeting point between savagery and civilization, Turner regarded the frontier as the "line of most rapid and effective Americanization," a purifying process by which the European colonists were first stripped of their culture by the wilderness, but eventually became the greatest defenders of republicanism and democracy at home and in the world. ${ }^{2}$ But before striding frontiers on the track to the West would become the symbol of American territorial expansion and its transgressive ideology, distant places offered themselves

\footnotetext{
${ }^{1}$ Victor Turner, The Ritual Process. Structure and Anti-Structure (Chicago: Aldine, 1969).

${ }^{2}$ Frederick J. Turner, The Significance of the Frontier in American History (London: Penguin, 2008) [1893].
} 
as a screen on which to project possible solutions to present dissatisfactions at home. The imaginary Asia as a land of plenty in early modern times, for example, incited many individuals to seek fortune in the service of East India Companies. ${ }^{3}$ Utopian literature of the sixteenth and seventeenth centuries favored far away islands as settings for the ideal society and emphasized the dangerous maritime passage that had to be undertaken to reach them. On the frontispiece of Francis Bacon's 1627 scientific program for a new science, Nova Atlantis, the idea that stimulation for progress must be sought beyond the horizon was allegorically expressed by the image of a ship returning with full-blown sails through the pillars of Heracles, bringing back knowledge and discoveries from distant lands. Gulliver's Travels by Jonathan Swift (1726) is a classic example of political satire in which the crossing of boundaries and the resulting estrangement serves to criticize a specific social order back home in the writer's native land.

The transgression of temporal borders is equally important in the culture of modernity. Overcoming traditions and reassuring that a break with the past has been made qualifies the modernist outlook just as much as its future-bound perspective. The first futuristic utopia L'an deux mille quatre cent quarante. Rêve s'il en fût jamais, published by Luis-Sébastien Mercier in 1771, helped to establish a view of time which would prove essential for the future-bound ideology of social change propagated by revolutionary French society in the following decades. Similarly revolutionaries of the nineteenth century, Karl Marx and others, insisted on breaks and ruptures in human history, which they regarded as the most significant historical events. In the early twentieth century the German intellectual Walter Benjamin considered the painting Angelus Novus by Paul Klee as emblematic of the propulsive (and destructive) forces of modernity, driving modern man unremittingly into the future and into the new. ${ }^{4}$ The very notion of innovation as a positively connoted means to overcome limits imposed by tradition, and its close association with concepts of progress and development is no more than two centuries old. ${ }^{5}$ The paradox is that, through the very processes of abating borders, modern Western societies were erecting new ones at the same time. Boundaries are a condition of the establishment and maintenance of social order and individual identity. The transgression or elimination of some boundaries paradoxically involves building new ones in their place.

The modern nation state of the nineteenth and twentieth centuries has defined itself by exercising sovereignty over a territorial unit and by people who shared a common mindset. The process of nation-building also involves erecting racial

\footnotetext{
${ }^{3}$ Ulrich Ufer, Welthandelszentrum Amsterdam. Globale Dynamik und modernes Leben im 17. Jahrhundert (Cologne: Böhlau, 2008), 87-88.

4 Walter Benjamin, "Über den Begriff der Geschichte," in Gesammelte Schriften Vol. I.2 (Frankfurt am Main: Suhrkamp, 1980), 691-704.

${ }^{5}$ Benoît Godin, "Meddle Not With Them That Are Given to Change," Innovation as Evil. Working Paper no. 6, Project on the Intellectual History of Innovation (Montreal: INRS. 2010).
} 
boundaries and delimitating which ethnicities are national and which are not. ${ }^{6}$ In their most extreme formulations these racial boundaries took the form of an essentialized biological division within the human species, as has been the case in some nation-states, colonies, even in former colonies with respect to their own minorities. ${ }^{7}$

This discussion of boundaries can also be extended to science. The three key elements of modern science (quantification, mensuration and specialization) provide further instances of how transgressing boundaries (in this case, the limits to knowledge), resulted in the production of new ones. It is not so much that these limits withdraw with each advance of knowledge; rather that, each answer to a set of problems opens the way to a few dozens more while making new limits apparent. Building on the fundamental boundary which Cartesian philosophy had drawn between the human subject and a nature perceived as a distinct object, the rise of nomothetic science over the course of the nineteenth century implanted a strict separation between the measurable and the non-measurable aspects of the world by dividing the search for truth from search for the good, the just or the beautiful. Concentrating on the quantifiable and the measurable, taxonomies drew ever finer borders, grouping clusters and variances within sub-groups. Modern science's inherent drive to erect boundaries and to categorize the world impacted on the constitution of science itself when its actors created distinctions between different branches of knowledge that would henceforth serve a splintered academic perception of the world. ${ }^{8}$ Disciplining the sciences, however, leads to contradictory effects in the long run when knowledge actors hide behind the fences of their disciplinary paradigms. As Thomas Kuhn noted, accepting the latter uncritically leads researchers to "puzzle solving" within thought determining and thought limiting frameworks instead of "problem solving" by finding innovative solutions outside the box. ${ }^{9}$ Andrew Abbott has argued convincingly that those successive divisions and subdivisions did not represent any progress but rather never-ending circles around a limited number of issues and principles. His history of the social science disciplines as a continuous redrawing of the same boundaries (along fractal patterns) leads him to argue that the boundaries between the disciplines are far less significant than broadly believed. ${ }^{10}$ Recently calls for trans-, multi-, pluri-, and interdisciplinary research have

\footnotetext{
${ }^{6}$ Paul R. Spickard, Race and Nation: Ethnic Systems in the Modern World (New York, Oxford: Routledge, 2005).

${ }^{7}$ Michèle Ducharme, "The Canadian Origins of South African Apartheid?," in Currents - Readings in Race Relations 3, 4 (1986): 2.

8 Immanuel Wallerstein, Open the Social Sciences. Report of the Gulbenkian Commission on the Restructuring of the Social Sciences (Stanford, CA: Stanford University Press, 1996), 13-29.

${ }_{9}$ Thomas Kuhn, The Structure of Scientific Revolutions (Chicago: University of Chicago Press, 1962), 3538.

${ }^{10}$ Andrew Abbott, "The Chaos of Disciplines," in Chaos of Disciplines (Chicago: University of Chicago Press, 2001).
} 
multiplied and become central in national and international research programs. ${ }^{11}$ It is expected in these times of economic crises and contested economic leadership that transcending the limits of specialization might provide innovative answers to the actual problems of society. In the wake of such discussions, the concepts of boundaries and borders themselves have become subjects of study in the social sciences. ${ }^{12}$

As with nation states and sciences, the economy is tearing down boundaries as much as it is erecting new ones. We are far from observing the fulfillment of the neoliberal ambition of a world bereft of borders, open to free circulation of capitals, goods, services, and persons. While modernization theory held that borders between rich and poor would be transcended in time though the forces of development, dependency theory and world system analysis have enlightened us as to how such borders constituted structural properties of the world system throughout capitalism's long history. ${ }^{13}$ The division of labor involves borders delimitating the different steps from investment to production, and to purchase and accumulation of profit. These borders are spatial and social and assign definite tasks to specific peoples and regions, thereby also creating systemic variance with regard to participation in the creation and appropriation of surplus value.

The workings of this basic pattern can be illustrated by the earliest waves of economic globalization during the constitutive phase of the modern world system which were driven to a large extent by price differentials on the sixteenth and seventeenth century world market: Central American silver and gold, acquired and transported at the minimum cost of labor by the Spaniards gained massively in value when entering the European trade cycle and were valued even higher when entering the East Asian market, where bullion was rarer and buyers were prepared to pay double the European price. ${ }^{14}$ Even though global silver markets integrated over time and world market prices converged towards the end of the seventeenth century, ${ }^{15}$ the strategy of connecting different economic zones and thus exploiting the borders created by market differentials would remain a basic requirement for the dynamic of capitalism. Today, the existence, maintenance and new production of economic borders still drives globalization - in the sense of the migration of labor, production sites and capital movements - by separating and re-connecting zones of low costs of production (labor, inputs, taxation) and zones with higher living standards that allow higher profits on the consumer market.

11 UNESCO, The World Social Science Report 2010 - Knowledge Divides (Paris: UNESCO Publishing, 2010), chapter 10.

${ }^{12}$ Michèle Lamont and Virág Molnár, "The Study of Boundaries in the Social Sciences," Annual Review of Sociology 28 (2002), 167-195.

${ }^{13}$ Immanuel Wallerstein, The Modern World-System, vol. 1-2. (New York: Academic Press, 1974, 1980).

${ }_{14}$ Dennis Flynn and Arturo Giraldez, "Born with a "Silver Spoon." The Origin of World Trade in 1571," Journal of World History 6, 2 (1995): 201-222.

${ }^{15}$ Matao Miyamoto and Yoshiaki Shikano, "The Emergence of the Tokugawa Monetary System in East Asian International Perspective," in Global Connections and Monetary History, 1470-1800, ed. Dennis Flynn, Arthur Giraldez and Richard von Glahn (Aldershot: Ashgate, 2003), 169-187. 


\section{BEYOND THE BOUNDARIES OF MODERNITY?}

The continuous erection of new borders, boundaries and frontiers is very much part of the modern project. For many observers of current affairs, we would now have entered a new period in which the world would have become boundless thanks to the ongoing process of globalization. Some commentators such as the widely read journalist Thomas L. Friedman even discern a leveling process that does away with obstacles, frontiers and confines creating this seemingly flat world facilitating the movement of people, commodities, money and information, and resulting arguably in a new "cultural hybridity." This discreet charm of globalization and its concurrent linguistic expressions of openness and transcendence of boundaries are communicated through the images and imaginaries of international media and are reinforced by the experience of a world coming to one's home through the computer screen. The notion of a boundless world has also been consolidated by easier and more frequent travel for business people and tourists. Such representations of a "flat" and boundless world as the common lot to humankind in the late twentieth and early twentyfirst centuries are being rightfully questioned. They belong to a socially positioned discourse about the world and only pertain to a few cosmopolitan elites. This social stratum could summarily be classified as coming predominantly from Western urban upper- and middle-class households with above average income and educational background. At the very top of this stratum one could find those working in international business, media and science. ${ }^{16}$ They may represent about $0.1 \%$ of the world's population.

The manner in which the world has been made smaller through the use of electronic communication is often cited as an example of the erosion of borders. The number of Internet users has been growing by about $450 \%$ in the last decade. Yet only a mere $28.7 \%$ of the world's population has some access to the Internet. In the Middle-East, Asia and Africa these rates have increased over the same period, to reach $29.8 \%, 21.5 \%$ and $10.9 \%$ respectively. There are over 5 billion people living in Africa, the Middle East and Asia and among them only 20\% share the experience of using the Internet including those with only limited and temporary access, and those that have some form of access but at a high cost and often outside their home. ${ }^{17}$

Similarly, only those with the right passport and those working for multinational companies or within other international professional infrastructures can experience this "boundless" world of global collaborations and affairs. They commute between urban global centers where they frequent the cosmopolitan quarters, eat the same food, buy the same consumer goods, communicate in a shared lingua franca, but overall barely engage with their local environment. Tourists are in a similar position, as tourism mostly only offers a narrow experience of otherness and the social settings

\footnotetext{
${ }^{16}$ Jonathan Friedman, "Globalization, Class and Culture in Global Systems," Journal of World Systems Research 6, 3 (2000): 652-655.

$17 \mathrm{http}: / /$ www.internetworldstats.com/stats.htm
} 
developed for tourists share very little with the world of those who provide them with services. ${ }^{18}$ Furthermore, tourism remains an activity restricted to populations with enough time and money. The discourse about today's apparent boundless global culture ignores such limits just as much as criticism and fears of a McDonaldization of international cultures turn a blind eye to questions of social hierarchies, classes and cultural exclusions. Identifying the experience of a flat world as pertaining to a cosmopolitan elite helps to understand to what extent the world is replete with obstacles for the greater majority. Anna Tomaszewska's study of Ukrainian border crossers at Polish borders and of the difficulties they encounter in the wake of EU expansion to the East certainly enlightens us as to how the existence of national borders remains relevant even in this context of global communication. In contradiction to scenarios of open boundaries, celebrated by neoliberal globalization discourses, this border, just like so many others, involves even stronger border controls than before.

\section{BORDER SCENARIOS}

The studies by David Simo, Ma Jian or Sarah Colvin, each in their own way, illustrate how languages and literatures show different sensitivities to the border and the boundary, both as a metaphor and as a real life phenomenon. The trilingual character of this journal, Eurostudia, entices etymological considerations about possible border scenarios involving the border itself, border-crossers and boarderguards. The meanings and usages of the notions of borders, Grenzen and frontières are broadly consistent with one another. While borders refer primarily to physical limits the word can also be used synonymously with boundaries which indicate the bounds or limits of anything whether material or immaterial. The same can be said of the German Grenze, and the French frontière or limite whose semantic field encompasses physical and metaphorical zones of contact including geographical areas, political units, fields of knowledge, and shared values.

The exhaustive Oxford English Dictionary does not acknowledge the existence of border-crossers or boundary-crossers, and yet they are a common phenomenon. The border-crosser, though, differs in important respects from the German Grenzgänger whose activity is not restricted to the crossing of borders. In fact, the border passage (Grenzübergang) is only one aspect of the Grenzgang. As Sabine von Mering also suggests by her usage of the term in her article on Jewish-German relations, a Grenzgang may also entail a particular approach to the Grenze, where there is a lingering along the border and possibly an appreciation of the sensation of inbetweenness itself. The latter meaning only re-emerges in the English language through the expressions walking the border, or walking the line, which cannot be turned into a noun. In French, the meaning of le passeur is largely restricted to the one who

${ }_{18}$ Jean-Paul Dumont, "A Matter of Touristic "Indifférence"," in American Ethnologist 11, 1 (1984): 139151. 
merely traverses the border, a commuter. It cannot be used to depict someone interested in the study of borders or in the experience of the border scenario as such. The difficulty in grasping in translation the multi-faceted connotations of the German term Grenzgänger is underlined by the divergent meanings of its direct renderings in French where the metaphorical dépasser ses limites means more of an enterprise beyond one's capacities and where the more concrete passage de la frontière refers, again, solely to the act of crossing the border.

In recognition of the existence of cultural barriers, the Grenzgänger has been professionalized by governments, NGOs and transnational companies in the figure of the cultural mediator (Kulturvermittler or attaché culturel). Mediating between different cultures requires constant transitory movement. But in order to facilitate understanding through communicating cultural particularities from one side to the other, generalization can hardly be avoided. Explaining cultural differences or translating between cultures the cultural mediator must constitute cultures as entities and typify their elements from his or her own perspective when suggesting contrasts and comparisons. The cultural mediator thus easily turns into a disseminator of personal experiences and opinions - stereotypical visions are much more easily transmitted than presentations that take into account the multiple discourses and controversies over the attribution of cultural meaning. As border-transitions and mediation across borders is always followed by new limitations and by the construction of new boundaries, the impossibility of avoiding essentializing cultures in trans-border communication poses a self-contradictory threat to the profession of the cultural mediator: the very task of helping to overcome cultural barriers may paradoxically also lead to their erection. ${ }^{19}$

Borders involve another possible scenario: the one where the gate-keeper shouts "Stop!". Administrations of modern nation states have called this figure boarder guard, Grenzbeamter, or agent frontalier. However, in all three languages it is the more antiquated term that reveals this figure's original purpose. The customs officer or tollkeeper, the Zöllner and the douanier reveal the fact that throughout a career that has lasted for millennia his or her primary duty involved collecting a payment for passage. The toll-keeper, Zöllner, douanier is the manifestation of those powers that create and maintain borders and at the same time collect the fee necessary to cross a given border. Crossing borders and boundaries presumes the capacity for payment of one kind or another. It also presumes leaving behind a token which in a pecuniary sense can simply be money, but in a more symbolic sense can include memories, valued objects, social networks, which are all aspects of identity.

Crossing borders is expensive, either in monetary, social, individual or symbolic terms. As Pierre Bourdieu has shown with his concept of habitus and the different

\footnotetext{
19 Alexandra Hausstein, "Grenzgänge, Grenzziehungen und Grenzüberschreitungen. Überlegungen zur diskursiven Macht von Kulturmittlern," ed. Asociación Mexicana de Profesores de Alemán VII/VIII (Encuentro AMPAL. Memorias, Mexico, 2008), 12-17.
} 
forms of capitals (economic, social, cultural), there is a close interdependence between social and symbolic boundaries. Climbing up the social ladder requires the acquisition of skills and manners necessary to adapt to a certain habitus into which one has not been born. And failure to read and understand symbolic boundaries may well cause failure to overcome social boundaries too. Similar to the fee paid when crossing state borders, the (cultural) capital necessary to cross social borders may well allow the social "tourist" only a short stay if his or her capital cannot buy permanent residency in the new social stratum. The parvenu is likely to lack the ease and nonchalance of the traditional possessors of a specific status. She or he runs the risk of falling into the traps of overdoing it, showing off and being cast out for having crossed the limits of what is considered acceptable. ${ }^{20}$ In other words, the toll fee required does not relieve the persons crossing social boundaries from their former identity traits: they enter neither with a clean sheet, nor are they in a position of achieving immediate social inclusion. And yet, attempts to free oneself of the stigma of previous social position also forbid the return to this initial status. Fees are paid in both directions.

Boundaries transform what passes through them. In the process any object may become an exotic curiosity. This idea of "trash to treasure" once helped early European world trade when cheap trifles were exchanged for commodities of high value, and, allegedly, land for mirror and glass. ${ }^{21}$ Exoticism increases the value of imports and the reputation of those who bring them. In an environment favorable to innovation, the border-crossers are received with anticipated trust in their capacity to innovate by doing things differently and by taking a fresh view on established conventions. Trash can become a treasure, but the opposite is also true. Positive expectations of newcomers can easily be turned upside down: valued, appreciated and needed on one side of the border, goods, commodities and people might be deprecated on the other. Such disdain is experienced by a great deal of global migrants and refugees.

From the perspective of the xenophobic, borders are the condition of security at home in an increasingly threatening and unpredictable world; they regard borders as embattled trenches rather than permeable transit zones. On the southern fringes of the US, at the Maghreb outposts of EU immigration control, or in urban gated communities, borders are erected as protective shields, thus promoting processes that have been described as "Balkanization." 22 Discursive exclusions can play a role similar to physical boundaries. Recent public debates in England and Germany, for

\footnotetext{
20 Pierre Bourdieu, Distinction. A Social Critique of the Judgement of Taste (Cambridge, MA: Harvard University Press, 1984), 95.

${ }^{21}$ Alexandra van Dongen (ed.), One Man's Trash is Another Man's Treasure. The Metamorphosis of the European Utensil in the New World (Rotterdam: Museum Boymans-van Beuningen, 1996).

${ }^{22}$ Jonathan Friedman, "Transnationalization, Socio-Political Disorder, and Ethnification as Expressions of Declining Global Hegemony," in International Political Science Review / Revue internationale de science politique 19, 3 (1998): 233-250.
} 
example, have shown prominent politicians disparaging immigrant groups for supposedly lacking the intelligence to learn the language and culture of residence. ${ }^{23}$ As the study by Helen Williams shows, the appearance of such discourses sometimes indicates profound changes in the political culture of a country. These physical and discursive exclusions reveal the darker side of the otherwise often joyful cosmopolitan excitement about cultural hybridity and trans-border exchanges. "The stranger," Zygmunt Bauman writes aptly, "is constantly ante portas - at the gate; but it is the presumed ill-will of the stranger, of a stranger conspiring to trespass, to break in and invade, that makes the gate tangible." ${ }^{24}$ Viewed with hostility the stranger's border crossing is often perceived as an intrusion and answered with strategies of exclusion. As Georg Simmel defined the stranger in his Exkurs über den Fremden, the stranger is the one who comes and stays, thus contrasting the visitor or the merchant whose arrival comprises, by definition, their not too distant departure. ${ }^{25}$ In her analysis of the Anglo-German author W.G. Sebald, Lynn Wolff presents one such case of strangeness and estrangement in the case of an author who spent his life living between borders.

Borders transform that which passes through them, but borders themselves can be mobile too. As they move, borders transform localities. Some localities and the people who live there can be quite suddenly pushed back from the centre to the periphery; others, as a result of wars and changing geographies, become the object of great tensions. This transformation is exemplified by Elżbieta Opiłowska's analysis of Polish-German border towns. The history of the present day city of Lwiw in the Ukraine also bears witness to the shifts of political borders: over the past centuries it has stood on Galician (Lew), Polish (Lwów), Austrian (Lemberg), Polish again (Lwów), Russian (Lwow) and finally Ukrainian (Lwiw) territory.

Economic borders can move even more swiftly than political borders and even though flexibility counts among the key qualifications of the modern worker, ${ }^{26}$ the geographic reorganization of the division of labor can leave behind a majority of employees unable to move and migrate at equal pace. Such is the case when financial investment, or economic and industrial activity abandon once thriving area as, for example, the Ruhr region in central Germany. Here, the misery of losing jobs, individual status and social continuity descended upon hundreds of thousands of miners and their families during the past twenty or thirty years and did not necessitate any active border crossing or migration on their part.

\footnotetext{
${ }^{23}$ Markus Porsche-Ludwig, "Sarrazin und die Verletzung der Meinungsfreiheit," in Zur Sache Sarrazin, ed. Jürgen Bellers and Henry Broder (Berlin: LIT, 2011), 41.

${ }^{24}$ Zygmunt Bauman, The Individualized Society (Cambridge: Polity Press, 2001), 92.

25 Georg Simmel, "Exkurs über den Fremden (1908)," in Untersuchungen über die Formen der Vergesellschaftung. Georg Simmel Gesamtausgabe, ed. Otthein Ramstedt, vol. 11 (Frankfurt am Main: Suhrkamp, 1992), 764-771.

${ }^{26}$ Richard Sennet, The Corrosion of Character, The Personal Consequences Of Work In the New Capitalism. (New York: Norton, 1998).
} 


\section{URBAN BORDER REGIMES}

Borders need to be understood as socially embedded and contextualized phenomena and the best site for their study is neither the self-evident barrier nor the tollhouse, but the city as a place where economic, cultural and social border regimes are manifested in more subtle ways. In fact, the history and present situation of Germany's Ruhr region as an urban agglomeration, and of the quarter DuisburgMarxloh in particular, provide worthwhile examples for how the border problematic of modern culture is inscribed into the city's social, cultural and economic topographies.

Stretching out along the river Ruhr between the towns of Münster, Hamm and Wuppertal to the north, east and south, and the river Rhine to the West, the Ruhr region has approximately 5.2 million citizens. With the beginning of coal mining during the early nineteenth century and the following settlement of iron and steel industries in the region, small towns like Dortmund and even villages of sometimes only a few hundred peasants, like Gelsenkirchen, turned into large towns over the span of only a few decades. Over the course of the twentieth century, they would grow to sizable cities and finally merge into the present Metropolenregion. Extreme demographic increase and the intensification of mining and steel industries were only possible on the basis of massive immigration. A first wave of immigrant labor arrived from the politically divided Polish territory, from Masuria and from East Prussia during the last decades of the nineteenth, and around the turn of the twentieth, century, when German industrialization gained momentum. Already by the 1890s over 25\% of the Ruhr region's working population was of eastern European descent and by 1915 this figure had risen to nearly $35 \% .{ }^{27}$

The immigrants' arrival reproduced linguistic and cultural differences within the growing cities. Far from integrating into a simple melting-pot, migrants set up societies in which they continued cultural activities from their homes and passed on a sense of identity to subsequent generations. By 1914 the "Ruhrpolen" were organized in over 1.000 societies, they printed their own newspapers and had established the third largest miners' labor union of the Ruhr area. ${ }^{28}$ From the point of view of the region's native peasant population of the mid and late nineteenth century, migrant workers and their cultural societies as well as the whole industrial venture itself were perceived as intruders who increasingly compromised their traditional agricultural world. While most Polish societies had managed to survive increasing nationalism during the First World War by showing solidarity to the German cause, their members were exposed to enforced cultural assimilation and increasing hostility among the German labor force during the interwar years. After Germany's invasion of

\footnotetext{
${ }^{27}$ Figures quoted in Anna Versteegh, De Onvermijdelijke Afkomst? De Opname van Polen in het Duits, Belgisch en Nederlands Mijnbedrijf in de Periode 1920-1930 (Hilversum: Verloren, 1994$), 71$.

${ }^{28}$ Klaus Bade, Pieter Emmer, Leo Lucassen and Jochen Oltmer (eds.), Enzyklopädie Migration in Europa. Vom 17. Jahrhundert bis in die Gegenwart München: Fink, 2007), 870.
} 
Poland in 1939, migrant societies came under severe attack and were either outlawed and forced to close or had to adapt to nationalist propaganda. ${ }^{29} \mathrm{~A}$ second wave of immigration beat the Ruhr region, when the young Federal Republic of Germany was in need of foreign labor to sustain the economy of its booming 1950s and 1960s. In this situation, border-crossers arrived from southern Europe, mainly from Italy and from Turkey, as guest workers recruited through bilateral treaties. As such they were expected to return eventually to their homelands, thus prolonging their status as strangers and complicating self-identification or acceptance by others as residents both in Germany and in the places they had left.

Cultural differences with distant geographical origins conglomerated and perpetuated in the cities of the Ruhr region. Today, the suburb Marxloh of the city of Duisburg is representative of how social, cultural, economic and other border regimes are manifested in the city. Rather than creating level and egalitarian hybridities as a result of global flows, the global processes of labor migration and economic long-term shifts should be understood as implementing local hierarchies and differentiation. Duisburg-Marxloh followed the general demographic trajectory of the Ruhr-region, growing from a small village of a few hundred peasants in the early nineteenth century into a suburb of nearly twenty thousand inhabitants today. Roughly one third of the quarter's present residents are foreigners and roughly two thirds have some form of migratory background. The number of Turkish residents is substantial and the quarter now accommodates Germany's largest Muslim community.

In a place that has been shaped by immigration over the past 120 years it would seem difficult to separate the native from the foreign. Nevertheless, cultural and, in particular, religious differences of the Muslim communities in Duisburg-Marxloh have in recent years redrawn the line between us and them and have raised the question whether the native should keep reign over the foreign. The public debate that most explicitly showed popular notions about the maintenance, alteration and reerection of cultural borders concerned the building of the Merkez Mosque at Duisburg-Marxloh in 2008, and more particularly the height of its minaret and the question, whether a muezzin would be allowed to call to prayer. ${ }^{30}$ From the point of view of the Muslim communities as well as of local politicians for integration, the mosque was a symbol of successful integration policies, being at the same time a sign of a growing sense of belonging and settlement on the one hand and a step towards institutional integration on the other. From the point of view of a group of residents that still identifies itself as local and claims supremacy in matters concerning the quarter's cultural identity, the mosque itself presented a manifestation of cultural intrusion. It seemed even more unacceptable that the minaret's height should exceed

\footnotetext{
${ }^{29}$ Ibid., 876-879.

${ }^{30}$ On the "Gebetsrufkonflikt" in Duisburg-Marxloh see e.g. Jörg Hüttermann, Das Minarett. Zur politischen Kultur des Konflikts um Islamische Symbole (München: Juventa, 2006), 180-186.
} 
the tower of the nearby Catholic Church of Saint Peter and Paul. Out of respect for local sentiments, the Muslim community agreed on the compromise to build a smaller minaret, and to refrain from publicly calling to prayer through a muezzin.

Urban spaces are structured by multiple boundaries and Berlin offers a case in point insofar as its boundaries have resulted from a variety of willful and strategic implementations: something that Nofar Sheffi discusses in detail. In the Ruhr area, struggles over the definition of spatial boundaries around quarters with high numbers of immigrants such as Duisburg-Marxloh or Dortmund-Nordstadt have been acted out both on a pragmatic as well as on a discursive level. It is in particular through emotionalizing the urban landscape that new borders are erected. DuisburgMarxloh has been marked by the stigma of a "no-go area" in the eyes of many inhabitants of the Ruhr area. Not only is there little incentive to take residence or to spend leisure in urban environments marked by an infrastructure of unemployment and impoverishment (run-down buildings, call centers, cell phone shops, take away eateries, gambling houses), but the quarter has so far also proved resistant to the habitual processes of gentrification which aims to attract artists to cheap studios and revelers to alternative nightlife and bars. Some of the discourses on the suburb by officials as well as by the wider public reflect the process of exclusion and stigmatization of which Marxloh has become a part. Even though crime rates in multi-ethnic Duisburg-Marxloh are not by any means higher than in other quarters of the Ruhr area with similar unemployment problems, both the local and national press have referred to the quarter as an "Angstraum" - a space of fear in which local population and even police forces feel threatened. ${ }^{31}$ Marxloh is also often quoted in the conservative and right-wing media in which its multi-ethnic social composition is described as a "ticking time-bomb," 32 which is then seen as representative for Germany as a whole. ${ }^{33}$ Similar representations in media and public discourses concern the quarter around Viehofer Straße in the Ruhr city of Essen, which has also been quoted as a "gefährlicher Ort" (dangerous place). ${ }^{34}$ By associating certain quarters and their inhabitants with emotions such as fear, aversion and contempt emotional border regimes create divisions and hierarchies in the city along lines that have already been indicated by wider concerns about security. Disturbances of the public order by crowds of unemployed youths, or street crimes by individuals and gangs easily get amalgamated in public discourse with fears over fundamentalist Islamic terrorism. ${ }^{35}$

Often reproached as setting up a "parallel society" and as being unwilling to integrate into a "German" society, the foreign communities of Duisburg-Marxloh

\footnotetext{
${ }^{31}$ Interview "Polizeipräsident Rolf Cebin: Kampf dem Angstraum," Der Westen, 29 August 2008.

32 "Ist Duisburg-Marxloh ein "Wunder" oder eine "tickende Zeitbombe"?," Blaue Narzisse, 19 March 2010.

33 "Das "Wunder von Marxloh" - mit Steuermillionen gefördert - heute ein Stützpunkt des Islamismus," Deutschlandwoche, 17 July 2010.

34 "Die Angst der Polizisten in deutschen Städten," Die Welt, 28 July 2008.

35 “Islamismus, Spenden aus Marxloh für die Hamas?," Der Westen, 15 July 2010.
} 
ironically share many of the problems with those who draw the borders that separate strangers from locals. Unemployment rates have risen to $25 \%$ in Duisburg-Marxloh since the heavy industries began to withdraw from the Ruhr-region in the 1980s, and they equally concern Germans as well as Turkish, Polish, Bulgarian or other migrant groups. While the decline of the coal and steel industries weighs heavily on the whole region, the economic borders that separate Marxloh from more thriving parts of the Ruhr-area have become particularly visible in the context of the Ruhr region's activities as European Cultural Capital in 2010. As the centers of Ruhr cities like Dortmund, Essen, Duisburg and Bochum received relatively generous funding to make core areas presentable for visitors, this has only increased the contrast with disfavored suburbs. German retail chains and some international companies have provided the gloss of urban consumerism that brands so many city centers in lookalike fashion. While the slogan of the Ruhr city of Essen is "Die Einkaufsstadt" (the shopper's city), the European Cultural Capital has had no similar effects on Duisburg-Marxloh. Even though this is a site par excellence, where Europe's different cultures mix and confront one another and even though thematic links to Istanbul as the second of three European Cultural Capitals in 2010 were evident, DuisburgMarxloh attracted very little attention by the organizers of the events.

\section{CONCLUSION}

Many discourses on the situation of today's global affairs negate the importance of borders and boundaries. Often such views have been influenced by neoliberal theories and cosmopolitan language which underline the importance, necessity and even stress the de facto reality of a boundless world. However, the essays of this special volume of Eurostudia on "Germany and Europe: Borders, and how to cross them," as well as this concluding chapter in particular, have shown that the picture is, in fact, much more complex. Modernity has its own traditions of tearing down boundaries and erecting new ones at the same time. As a Weberian ideal type, the border guard in its many guises seems to deserve more academic attention in the context of discussions of boundaries, border passages and intercultural phenomena. Also, the fact that border crossing is expensive, of which the border guard's natural function to collect the toll fee has reminded us, is only rarely addressed by the experts of global fluxes and transit cultures.

Mathieu Denis

dma@cmb.hu-berlin.de

Ulrich Ufer

ulrich.ufer@umontreal.ca 